() Веклич К.А., Попов М.М., Лядова Т.І., Мартиненко О.В., Сорокіна О.Г., 2021

doi:10.37321/immunology.2021.1-2-04

удК 616.915-097

\title{
ОСОБЛИВОСТI ЕКСПРЕСIÏ TOLL-LIKE PЕЦЕПTOPIB 9 ТИПУ НА ІМУНОКОМПЕТЕНТНИХ КЛІТИНАХ ПЕРИФЕРІЙНОЇ КРОВІ ПАЦІЄНТІВ З КОРОВОЮ ІНФЕКЦІЄЮ РІЗНОГО СТУПЕНЯ ТЯЖКОСТІ
}

\author{
ВЕКЛИЧ К.А., ПОПОВ М.М., ЛЯДОВА Т.І., МАРТИНЕНКО О.В., СОРОКІНА О.Г. \\ Харківський національний університет імені. В.Н.Каразіна, Харків
}

Робота виконана в рамках науково-дослідної роботи (НДР) кафедри загальної та клінічної імунології та алергології медичного факультету Харківського національного університету імені В. Н. Каразіна «Роль імунних, аутоімунних та метаболічних розладів у патогенезі інфекційного процесу, що викликаний бактеріями, вірусами, вірусно-бактеріальними асоціаціями при гострому, затяжному та хронічному перебігу хвороби та оптимізація засобів лікування» (№ держреєстрації 0117U004874)

Кір - висококонтагіозне вірусне інфекційне захворювання, яке характеризується розвитком загальноінтоксикаційного, лихоманкового, катарального синдромів, кон'юнктивітом та розвитком типового п'ятнисто-папульозного висипу. Персистенція вірусу кору в організмі людини призводить також до імуносупресії, що в свою чергу є передумовою високої сприйнятливості ураженого організму до приєднання різних вторинних патогенів.

Під час останнього спалаху кору, що спостерігався на території України у 2017-2019 роках, високі показники смертності були обумовлені не тільки дією самого вірусу, але й приєднанням вторинної бактеріальної флори та розвитком позагоспітальних пневмоній, що на фоні імуносупресії, викликаної безпосередньою дією вірусу, мали тяжкий перебіг навіть за умови використання потужних антибактеріальних засобів.

Важливою ланкою захисту макроорганізму від проникнення патогенів $€$ вроджена імунна відповідь, що використовує рецептори розпізнавання образів (англ. - Pattern Recogniton Receptors, PRR) для виявлення мікроорганізмів, що проникли в організм людини. PRR розпізнають ендогенні та екзогенні ліганди, у тому числі і асоційовані з патогенами молекулярні патерни (англ. - Pathogen-associated molecular patterns, PAMPs), що являють собою збережені хімічні мотиви, які експресуються мікроорганізмами. Найбільш повно охарактеризованим типом рецепторів розпізнавання образів, що являють собою важливі модулятори вродженої імунної відповіді завдяки здатності розпізнати мікроорганізми, локалізовані як у міжклітинному просторі, так і всередині клітин, $€$ Toll-like рецептори (TLR). Після виявлення PAMPs, TLR запускають каскад передачі сигналів, що призводить до продукції медіаторів запалення. Toll-like рецептори $є$ найбільш повно охарактеризованим типом рецепторів розпізнавання образів і являють собою важливі модулятори вродженої імунної відпо- віді, оскільки вони здатні розпізнати мікроорганізми, локалізовані як у міжклітинному просторі, так і всередині клітин. Той факт, що TLR широко представлені у клітинах організму, підтверджує їх центральну роль у розпізнаванні потенційних патогенів. Лігандами для TLR виступає дволанцюгова РНК (дРНК), одноланцюгова РНК (оРНК), вірусна та бактеріальна РНК або неметильовані CPG мотиви ДНК, що з'являються в результаті гідролітичної деградації мікроорганізмів [1, 2].

Одним з важливих TLR $€$ Toll-like рецептор 9 типу. Активація експресії цього рецептора та передача сигналу із його залученням є важливими механізмами запуску вродженої імунної відповіді, що призводить до активації різних структур в залежності від типу клітин. У конвекційних (кДК) та плазмоцитоїдних (пДК) дендритних клітинах, макрофагах TLR9 активують каскад передачі сигналу, кульмінацією якого є продукція прозапальних цитокінів - ФНП $\alpha$, ІЛ-6 та ІЛ-12 та інтерферону 1 типу [3, 4]. Також було продемонстровано, що TLR9 є важливим у захисті організму від ураження легеневої тканини, викликаної S.Pneumoniae та S.aureus [5-8].

Не дивлячись на розуміння важливості TLR9 у активації вродженої імунної відповіді на проникнення патогенів, роль цього рецептора у захисті організму від корової інфекції, а також зв'язок рівню експресії даного рецептора з рівнем та характером реакції цитокінової мережі та станом специфічної імунної відповіді досліджена недостатньо. Саме тому, враховуючи значну кількість пацієнтів з коровою інфекцією, що знаходились на лікуванні у КЗОЗ КНП ХОР ОКІЛ, імунологічні порушення, що були виявлені у цих пацієнтів [9], а також значну кількість пацієнтів, що мали бактеріальні ускладнення з боку респіраторного тракту, вважалось цікавим дослідити рівень експресії Toll-like рецепторів 9 типу у цієї когорти пацієнтів та встановити зв'язок між рівнем його експресії, ступенем імунологічних порушень та наявністю ускладнень. 
Мета дослідження: визначення рівню експресії Toll-like рецепторів 9 типу на лімфоцитах та моноцитах периферійної крові у пацієнтів 3 кором різного ступеня тяжкості як з ускладненнями, так і без них.

\section{МАТЕРІАЛИ ТА МЕТОДИ}

У дослідження було включено 65 пацієнтів з діагнозом «кір», що знаходились на лікуванні у КЗОЗ КНП ХОР ОКІЛ в період з 2017 до 2019 роки. Критеріями залучення до дослідження були наявність кору різного ступеня тяжкості, як з наявністю ускладнень, так і без них. Пацієнти були розподілені на 4 групи, в залежності від тяжкості перебігу захворювання та наявності ускладнень. У 1 групу було включено пацієнтів, що мали захворювання середнього ступеня тяжкості без ускладнень та знаходились на лікуванні у загальному відділенні $(n=20)$; у 2 групу увійшли пацієнти з кором середнього ступеню тяжкості, що мали ускладнення у вигляді позагоспітальної пневмонії та знаходились на лікуванні у загальному відділенні $(n=20)$; у 3 групу було включено пацієнтів з кором тяжкого ступеня тяжкості, що не мали ускладнень та знаходились на лікуванні у відділенні реанімації та інтенсивної терапії (n=16); група 4 включала в себе пацієнтів з кором тяжкого ступеня тяжкості, що мали ускладнення у вигляді позагоспітальної пневмонії та знаходились на лікуванні у відділенні реанімації та інтенсивної терапії

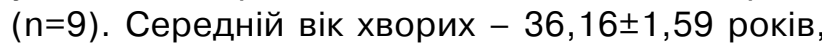
жінок - 48\%, чоловіків - 52\%. Хворі зверталися до стаціонару на 5,18 0,15 день від початку

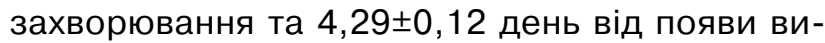
сипань. Діагноз встановлювався хворим на підставі наявності типових клінічних ознак захворювання (катаральний та інтоксикаційний синдроми, синдром ураження очей, синдром енантеми та екзантеми з типовою стадійністю появи та зникнення висипань), даних об'єктивного, інструментального та лабораторного методів дослідження, епідеміологічних даних (контакт із хворими зі встановленим діагнозом “кір"). Наявність пневмонії підтверджувалася за допомогою даних рентгенографії органів грудної клітини. Усі пацієнти відмічали проведення у дитинстві вакцинації проти кору. Контрольну групу склали 20 добровільних донорів, що на момент відбору зразків крові не мали клінічних ознак кору, не контактували із хворими на кір та не мали критеріїв виключення (наявність супутніх гострих та хронічних захворювань з боку різних органів та систем, імуносупресивних та аутоімунних захворювань, прийом імуносупресивних препаратів, проведення оперативних втручань за 6 місяців до госпіталізації з приводу кору, пологи за 6 місяців до госпіталізації з приводу кору). Усі добровільні донори відміча- ли наявність у дитинстві вакцинації проти кору та ніколи не хворіли на кір протягом життя.

Усім пацієнтам у день надходження до стаціонару проводилось визначення у суспензії лейкоцитів рівню експресії Toll-like рецепторів 9 типу. Дослідження проводилось з використанням методу проточної цитометрії з використанням набору моноклональних антитіл TLR9 (CD123+) (ФРН) згідно з інструкцією виробника. Також методом твердофазного імуноферментного аналізу за допомогою наборів реагентів АТ "Вектор-Бест" (Російська федерація), згідно інструкції виробника, проводилось вивчення концентрації у сироватці крові про- та протизапальних цитокінів (ІЛ-1, ІЛ-6, ІЛ-4, ІЛ-10) та інтерферонів альфа і гамма та визначення рівня у сироватці крові вірус-специфічних імуноглобулінів класів $M, A$ та $G$ з рівнем авідності останніх з використанням тест-систем фірм "ХЕMA" (Україна), "The Native Antigen Company" (США) та "Вектор-Бест" (Російська федерація) згідно з інструкцією виробника. Також було проведено кореляційний аналіз між показниками рівню експресії Toll-like рецеторів та концентрації у сироватці крові прозапальних цитокінів та інтерферонів альфа і гамма. Статистична обробка отриманих даних проводилась за допомогою програми IBM SPSS Statistics 22.0. Дані у таблицях представлені у вигляді середньої арифметичної (M) \pm середня помилка середньої арифметичної (m). При інтерпретації значущості різниці результатів використовували критерій Манна-Уітні, критичною величиною рівня значущості вважали $p<0,05$. При проведенні кореляційного-регресійного аналізу використовувався коефіцієнт кореляції Пірсона (критичне значення коефіцієнту Стьюдента р 0,05).

\section{РЕЗУЛЬТАТИ}

Вивчення рівню про- та протизапальних цитокінів, ІНФ альфа та гамма продемонструвало значні зміни рівнів вказаних показників в усіх досліджуваних групах. У пацієнтів 1 групи рівень ІЛ-1 та ІЛ-6 в сироватці крові підвищився у 3,9 разів, ІНФ $\alpha$ - у 2,8 разів, ІНФ - у 2,5 рази, ІЛ-4 та ІЛ-10 - у 3,7 та 3,6 разів; у пацієнтів 2 групи - вказані показники зросли у 3,2; 3,2; 2,$4 ; 1,7 ; 3,0$; та 2,8 разів, відповідно. У пацієнтів 3 групи рівень ІЛ-1 підвищився у 2,6 разів, ІЛ-6 - у 1,9 разів, ІНФ $\alpha$ - 1,7 разів, ІНФ $\gamma-$ 1,3 рази, ІЛ-4 - 1,4 рази, ІЛ-10 - 1,1 рази. У пацієнтів 4 групи - рівні ІЛ-1, ІЛ-6, ІЛ-4 та ІЛ10 підвищились у 1,03, 1,01, 1,04 та 1,06 разів, відповідно; рівні ІНФ $\alpha$ та ІНФ у у пацієнтів цієї групи були нижчими, ніж у осіб контрольної групи - у 1,06 та 1,1 рази, відповідно. (Рис. 1). 


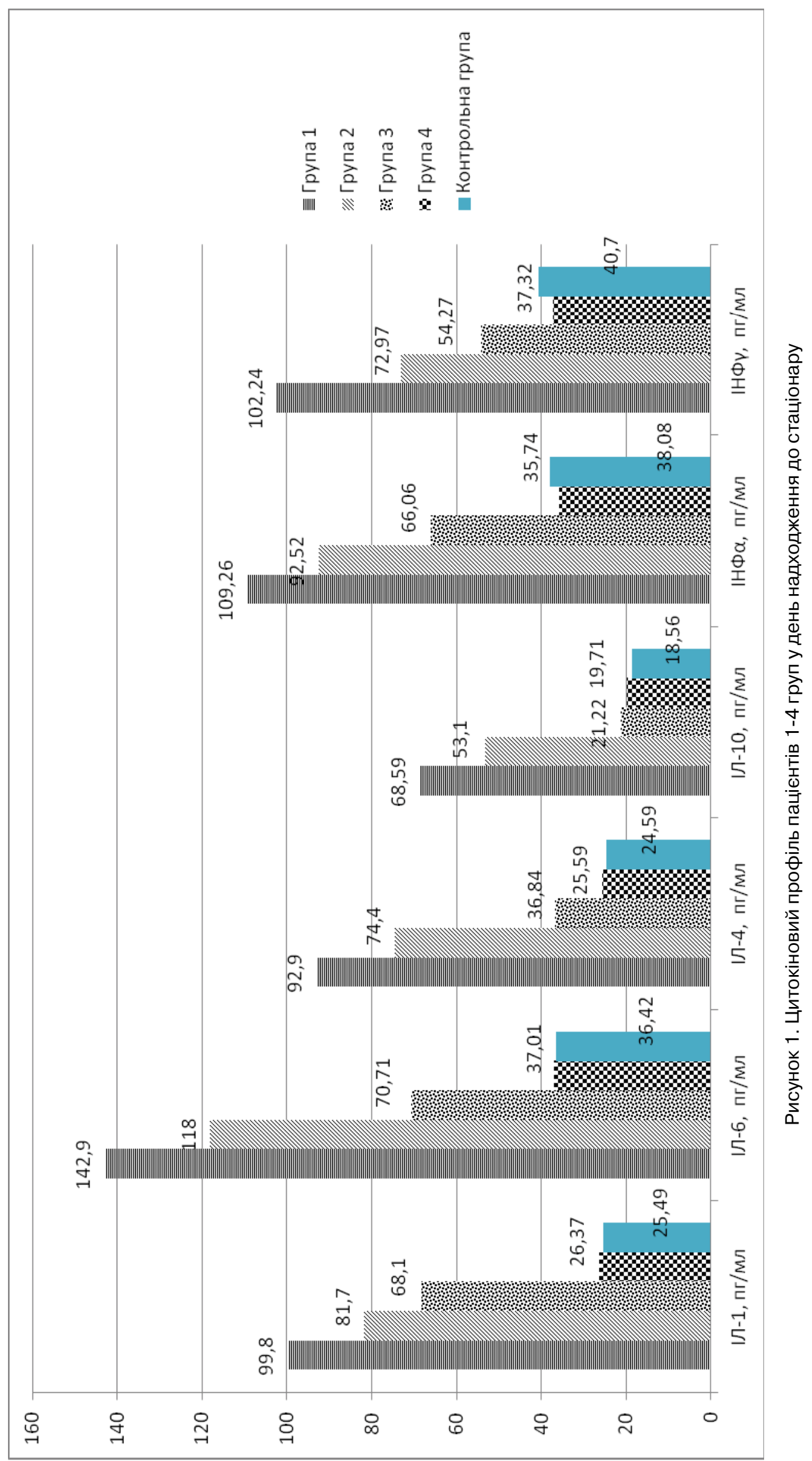


Дослідження рівнів специфічних антитіл та авідності IgG у день надходження до стаціонару продемонструвало зниження їх рівнів по відношенню до осіб контрольної групи у всіх групах пацієнтів. У порівнянні з показниками осіб контрольної групи, у пацієнтів 1 групи рівень IgA був знижений у 1,13 разів, IgG - був знижений у 1,2 рази, авідність IgG була знижена в 1,09 разів; у пацієнтів 2 групи показники були знижені у 1,7;
1,28 та 1,17 разів, відповідно. У пацієнтів 3 групи рівень IgA був знижений у 2,42 рази, IgG - був знижений у 1,75 разів, авідність IgG була знижена в 1,37 разів; у пацієнтів 4 групи показники були знижені у 3,$4 ; 1,98$ та 1,76 разів, відповідно. Також у пацієнтів 1-4 груп була зареєстрована наявність Ig класу M, що були відсутніми у осіб контрольної групи (Рис. 2, 3).

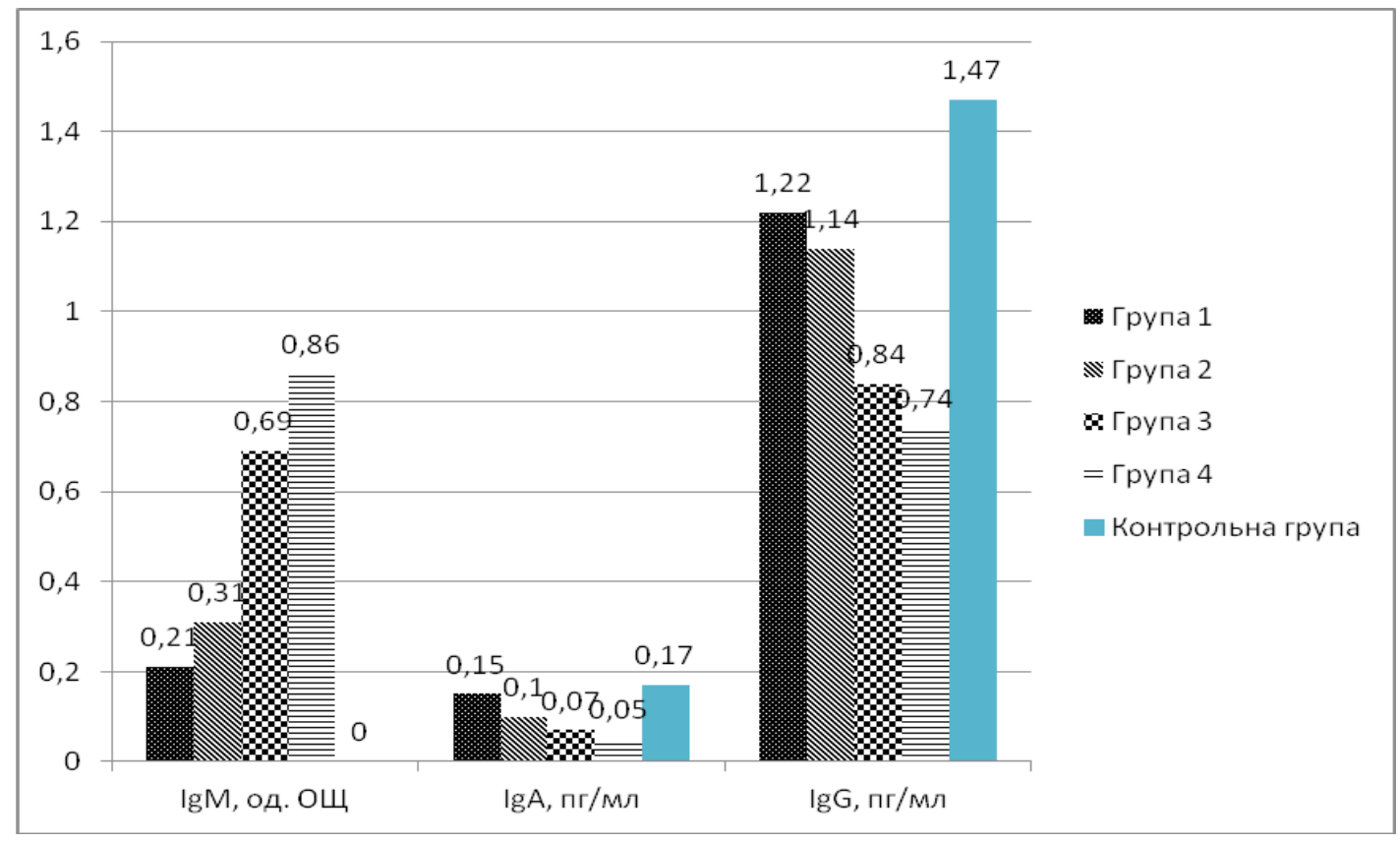

Рисунок 2. Рівні IgA, IgM, IgG у хворих 1-4 груп у день надходження до стаціонару

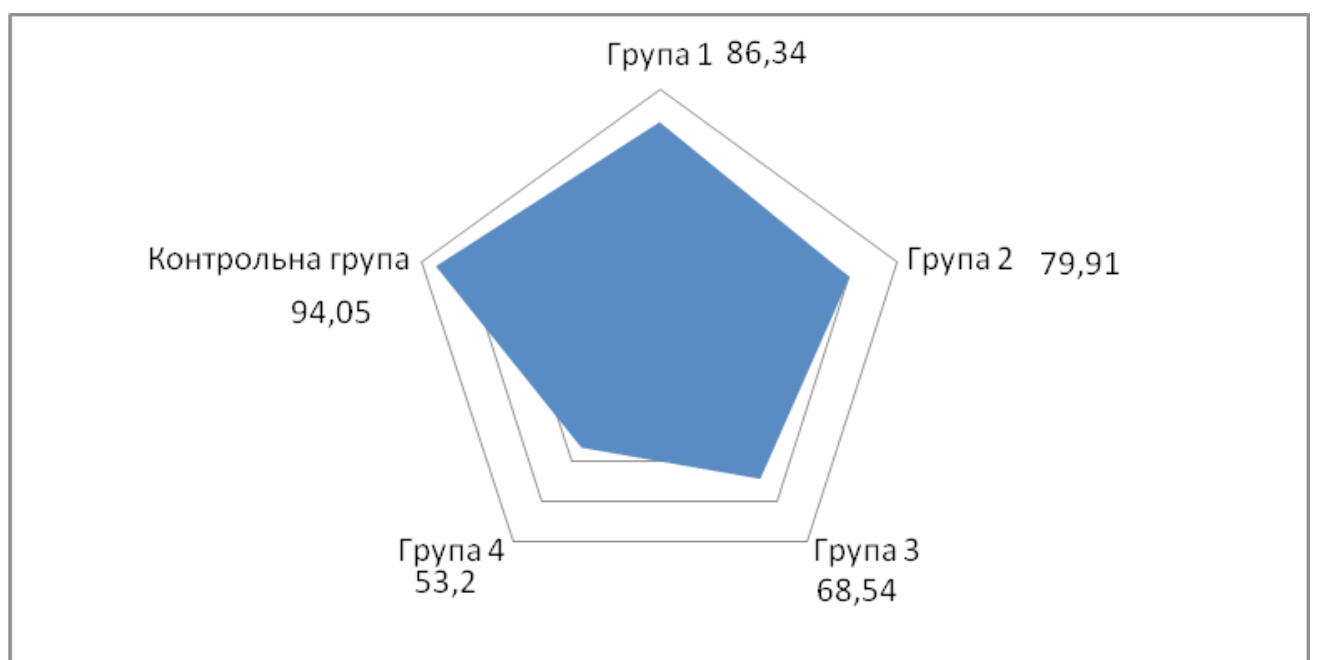

Рисунок 3. Авідність IgG у хворих 1-4 груп у день надходження до стаціонару

Аналіз даних, отриманих при вивченні рівню експресії Toll-like рецепторів 9 типу, продемонстрував наступні зміни: у пацієнтів 1 групи рівень експресії TLR9 був у 2,53 рази вищим, ніж у осіб контрольної групи; у пацієнтів 2 групи - у
1,96 разів вищим, ніж у осіб контрольної групи; у пацієнтів 3 групи - у 1,33 рази, а у пацієнтів 4 групи - у 1,35 разів нижчий, ніж у осіб контрольної групи (Табл. 1). 
Рівні експресї̈ TLR9, показники цитокінового профілю та специфічної імунної відповіді пацієнтів 1-4 груп у день надходження до стаціонару

\begin{tabular}{|c|c|c|c|c|c|}
\hline Показник & $\begin{array}{l}\text { Група } 1 \\
(n=20)\end{array}$ & $\begin{array}{l}\text { Група } 2 \\
(n=20)\end{array}$ & $\begin{array}{l}\text { Група } 3 \\
(n=16)\end{array}$ & $\begin{array}{c}\text { Група } 4 \\
(n=9)\end{array}$ & $\begin{array}{c}\text { Контрольна група } \\
(\mathbf{n}=20)\end{array}$ \\
\hline ТЛР9+ СD123+, \% & $2,13 \pm 0,34^{\star}$ & $1,65 \pm 0,26^{\star}$ & $0,73 \pm 0,07$ & $0,62 \pm 0,04$ & $0,84 \pm 0,02$ \\
\hline ІНФ $\alpha$, пг/мл & $109,26 \pm 6,74^{\star}$ & $92,52 \pm 2,21^{*}$ & $66,06 \pm 3,54^{*}$ & $35,74 \pm 3,95$ & $38,08 \pm 2,34$ \\
\hline ІНФ $\gamma$, пг/мл & $102,24 \pm 4,41^{*}$ & $72,97 \pm 3,45^{\star}$ & $54,27 \pm 2,66^{*}$ & $37,32 \pm 3,94$ & $40,7 \pm 2,29$ \\
\hline ІЛ-1, пг/мл & $99,8 \pm 26,83^{*}$ & $81,7 \pm 9,87^{\star}$ & $68,10 \pm 7,71^{\star}$ & $26,37 \pm 2,33$ & $25,49 \pm 1,88$ \\
\hline ІЛ-6, пг/мл & $142,9 \pm 21,05^{\star}$ & $118,0 \pm 17,84^{*}$ & $70,71 \pm 7,54^{*}$ & $37,01 \pm 9,00$ & $36,42 \pm 2,02$ \\
\hline ІЛ-4, пг/мл & $92,9 \pm 5,88^{*}$ & $74,4 \pm 7,04^{*}$ & $36,84 \pm 4,79^{\star}$ & $25,59 \pm 4,92$ & $24,59 \pm 2,02$ \\
\hline ІЛ-10, пг/мл & $68,59 \pm 6,02^{*}$ & $53,1 \pm 4,42^{*}$ & $21,22 \pm 2,24$ & $19,71 \pm 2,73$ & $18,56 \pm 1,66$ \\
\hline IgM, од. ОЩ & $0,21 \pm 0,06^{\star}$ & $0,31 \pm 0,06^{*}$ & $0,69 \pm 0,09^{*}$ & $0,86 \pm 0,13^{*}$ & 0 \\
\hline $\operatorname{lgA}$, пг/мл & $0,15 \pm 0,06$ & $0,1 \pm 0,02$ & $0,07 \pm 0,02$ & $0,05 \pm 0,01^{*}$ & $0,17 \pm 0,05$ \\
\hline IgG, пг/мл & $1,22 \pm 0,13$ & $1,14 \pm 0,1$ & $0,84 \pm 0,11^{*}$ & $0,74 \pm 0,10^{*}$ & $1,47 \pm 0,13$ \\
\hline Авідність, \% & $86,34 \pm 1,16^{\star}$ & $79,91 \pm 1,51^{\star}$ & $68,54 \pm 1,59^{*}$ & $53,2 \pm 2,02^{*}$ & $94,05 \pm 0,47$ \\
\hline
\end{tabular}

** p<0,05 між показниками хворих та контрольної групи

Проведення кореляційного аналізу Пірсона, проведеного щодо показників в день надходження пацієнтів до стаціонару, продемонструвало наявність прямого кореляційного зв'язку між рівнем експресії TLR9 та рівнем у сироватці крові інтерферону альфа, інтерферону гамма та прозапальних цитокінів (ІЛ-1 та ІЛ-6). У відношенні протизапальних цитокінів - інтерлейкінів 4 та 10 - встановлено зворотній кореляційний зв'язок.

У відношенні ІНФ альфа у всіх досліджуваних групах виявлено прямий високий кореляційний зв'язок, коефіцієнт кореляції $(r)$ становив у 1 групі +0,80; у 2 групі +0,79; у 3 групі $+0,77$ та в 4 групі $+0,74$; залежність ознак в усіх групах була статистично значущою $(p<0,05)$. Кореляційний зв'язок між показниками рівню експреciї TLR9 та рівнем IHФү коливався від слабкого до помітного та становив у 1 групі $+0,23$ (слабкий), у 2 групі +0,65 (помітний); у 3 групі $+0,54$ (помітний); у 4 групі +0,42 (помірний); залежність ознак в усіх групах статистично значуща $(p<0,05)$. Визначення кореляційного зв'язку між рівнем експресії TLR9 та рівнем IЛ-1 встановило прямий кореляційний зв'язок між показниками, при чому у пацієнтів 1-3 групи залежність ознак була статистично значущою, а у пацієнтів 4 групи - статистично незначущою $(p>0,05)$; коефіцієнт кореляції між TLR9 та IЛ-1 у пацієнтів 1-4 груп становив, відповідно, +0,79; +0,49; +0,53 та $+0,65$. Кореляційний зв'язок між рівнем експреciї TLR9 та рівнем у сироватці крові інтерлейкіну-6 коливався від вельми високого (у пацієнтів
1 та 4 груп) до високого (у пацієнтів 2 та 3 груп). Показники коефіцієнту кореляції у відношенні рівня ІЛ-6 становили: 1 група $+0,95 ; 2$ група +0,79; 3 група + 0,81; 4 група +0,93.

у відношенні протизапальних цитокінів інтерлейкіну 4 та 10 - встановлено негативний кореляційний зв'язок з рівнем експресії TLR9. Статистична значущість залежності між показниками, що вивчалися в усіх групах по відношенню до усіх показників, була відсутньою $(p>0,05)$, а сила зв'язку коливалась від слабкої $(-0,3)$ до високої $(-0,76)$.

\section{ОБГОВОРЕННЯ}

Вивчення цитокінового профілю хворих на кір виявило три типи цитокінового реагування на інфекційний процес: нормореактивний, дисоціативний та гіпореактивний. Нормореактивний тип цитокінового реагування був притаманний пацієнтам 1 та 2 груп, у яких захворювання мало середньотяжкий перебіг та характеризувалось статистично значущим $(p \leq 0,05)$ підвищенням рівнів про- та протизапальних цитокінів та інтерферонів у порівнянні з особами контрольної групи. У пацієнтів 3 групи, у яких захворювання мало тяжкий перебіг та не супроводжувалось розвитком ускладнень, виявлено дисоціативний тип цитокінового реагування, який характеризувався значущим підвищенням рівнів прозапальних цитокінів та низьким рівнем протизапальних цитокінів, та ІНФ $\alpha$ та IHФ $\gamma$. Пацієнти 4 групи, у яких захворювання мало тяжкий перебіг та супроводжувалося роз- 
витком пневмонії, мали гіпореактивний тип цитокінового реагування, який характеризувався низькими рівнями про- та протизапальних цитокінів, концентрації яких були дещо вищими за рівень осіб контрольної групи, та інтерферонів, рівні яких були нижчими за показники контрольної групи. В день надходження до стаціонару рівні про- та протизапальних цитокінів у сироватці крові були підвищеними у всіх групах пацієнтів у порівнянні з особами контрольної групи. Не дивлячись на значні досягнення у розумінні особливостей продукціїі цитокінів імунокомпетентними клітинами у відповідь на різноманітні вірусні патогени, характер реакції цитокінової мережі при коровій інфекції різних ступенів тяжкості у сучасній літературі висвітлено недостатньо.

Дослідження рівнів специфічних антитіл та авідності IgG у день надходження до стаціонару продемонструвало зниження їх рівнів по відношенню до осіб контрольної групи у всіх групах пацієнтів, при чому найбільш низькі показники було зареєстровано у пацієнтів 4 групи, що мали тяжкий перебіг захворювання та розвиток пневмонії. Та навпаки, більш легкий та сприятливий перебіг захворювання спостерігався у пацієнтів, що на початку захворювання мали більш низькі рівні вірус-специфічних імуноглобулінів класу M - 1 та 2 групи, а більш тяжкий - у пацієнтів 3 та 4 групи, що на початку захворювання мали значне підвищення рівнів цих імуноглобулінів. Дослідження рівнів вірус-специфічних IgA продемонструвало, що захворювання з більш тяжким перебігом розвивається на фоні значного зниження рівнів його показників, у той час як захворювання із середньотяжким перебігом супроводжується незначними змінами показника. А.П. Топтигіна та співавтори [10] у своєму дослідженні продемонстрували, що в групі пацієнтів 3 гострими проявами корової інфекції, які не були вакциновані проти кору, спостерігаються високі рівні вірус-специфічних IgM та підвищення концентрації низькоавідних IgG; у зразках крові групи пацієнтів з гострими проявами захворювання, що раніше були вакциновані проти кору, виявлялися незначна концентрація $\lg$, специфічних до вірусу кору, високі рівні вірус-специфічних IgA та високоавідних IgG. Автори вважають, що люди, які впродовж життя втратили захисний рівень антитіл, можуть захворіти кором, проте хвороба в них має нетяжкий або навіть атиповий перебіг, оскільки в організмі таких пацієнтів зберігаються Т- та В-клітини пам'яті, що мають змогу швидко відреагувати на проникнення вірусу та зупинити його дисемінацію. Пацієнти, що були вакциновані, але не сформували імунної відповіді, або ж ті, що не були вакциновані взагалі, скоріш за все, будуть мати тяжкий перебіг захворювання.
Проведене нами дослідження виявило, що в пацієнтів 1 та 2 груп, що мали нормореактивний тип цитокінового реагування та достовірно вищі рівні IgA та IgG, рівень експресії TLR9 на мононуклеарах переферійної крові був вищим, ніж у осіб контрольної групи; у пацієнтів 1 групи рівень експресії TLR9 був у 2,53 рази, а у пацієнтів 2 групи - у 1,96 разів вищим, ніж у осіб контрольної групи. У пацієнтів 3 групи, що мали дисоціативний тип цитокінового реагування та більш значне, у порівнянні 3 пацієнтами 1 та 2 груп, зниження рівнів IgA та IgG, рівень експресії TLR9 був у 1,33 рази нижчий, ніж у осіб контрольної групи. У пацієнтів 4 групи, що мали гіпореактивний тип цитокінового реагування та статистично значуще зниження рівнів IgA та IgG, рівень експресії TLR9 був найнижчим; у пацієнтів цієї групи показник експресії TLR9 був у 1,35 разів нижчий, ніж у осіб контрольної групи.

Звертає на себе увагу той факт, що серед пацієнтів з нормореактивним типом цитокінового реагування у пацієнтів 2 групи, у яких захворювання мало середньотяжкий перебіг, але супроводжувалось розвитком пневмонії, підвищення рівню експресії TLR9 було менш значним, у порівнянні з пацієнтами 1 групи, що ускладнень не мали. Також звертає на себе увагу значне зниження рівню експресії TLR9 у пацієнтів 4 групи, що мали тяжкий перебіг захворювання з розвитком позагоспітальної пневмонії.

Враховуючи отримані дані, можна зробити висновок про важливе значення активної експресії рецепторів розпізнавання образів, зокремa Toll-like рецепторів 9 типу, у розвитку активної імунної відповіді, спрямованої на елімінацію патогену, а також як у тяжкості перебігу захворювання, так і при розвитку ускладнень.

Вчасна та значна активація експресії Toll-like рецепторів 9 типу $€$ запорукою адекватної та доцільної стимуляції імунної відповіді організма-хазяїна на проникнення патогену. Зниження активності експресії TLR9 може розглядатися як передумова порушення цитокінового реагування на проникнення вірусу кору, а також розвитку бактеріальних ускладнень вірусних інфекцій, що супроводжуються імуносупресією.

\section{ВИСНОВКИ}

Тяжкість перебігу корової інфекції асоціюється 3 рівнем експресії Toll-like рецепторів 9 типу.

Рівень експресії TLR9 знаходиться у прямому кореляційному зв'язку з активністю продукції прозапальних цитокінів, інтерферонів альфа та гамма і може розглядатися як фактор, що впливає на стан імунної відповіді на корову інфекцію.

Зниження активності експресії TLR9 на мононуклеарах може розглядатися як фактор тяж- 
кості перебігу корової інфекції і її ускладнень, ризику розвитку бактеріальної пневмонії.

Дослідження порушення активності експресії TLR9 на імунокомпетентних клітинах периферійної крові може використовуватися для більш глибокого розуміння порушень імунної системи у пацієнтів із вірусними захворюваннями у якості предиктору та можливого фактора тяжкого перебігу захворювання та розвитку ускладнень.

\section{ЛITEPATУРA}

1. Kumar V. Toll-like receptors in immunity and inflammatory diseases: Past, present, and future. Int immunopharmacology, Vol. 59 (2018): 391-412, doi: 10.1016/j.intimp.2018.03.002

2. Lester S., Li K. Yoll-loke receptors in antiviral immunity. J.Mol.Biol 2014, 426(6): 12461264, doi: 10.1016/j.jmb.2013.11.024

3. Combes, A., Camosseto, V., N'Guessan, P. et al. BAD-LAMP controls TLR9 trafficking and signalling in human plasmacytoid dendritic cells. Nat Commun 8, 913 (2017). https://doi. org/10.1038/s41467-017-00695-1

4. Sasai M, Linehan MM, Iwasaki A. Bifurcation of Toll like receptor 9 signaling by adaptor protein 3. Science. 2010;329:1530 1534. doi: 10.1126/science. 1187029

5. Barbara Albiger, Sofia Dahlberg, Andreas Sandgren et all, Toll-like receptor 9 acts at an early stage in host defence against pnumococcal infection. Cell. Microbiol, 2007 Mar; 9(3):633-44. https://doi.org/10.1111/j.14625822.2006.00814.x

6. Bhan U, Lukacs NW, Osterholzer JJ, Newstead MW, Zeng X, Moore TA, McMillan TR, Krieg AM, Akira S, Standiford TJ. TLR9 is required for protective innate immunity in Gramnegative bacterial pneumonia: role of dendritic cells. J Immunol. 2007;179:3937-3946. doi: 10.4049/jimmunol.179.6.3937

7. Bhan U, Trujillo G, Lyn-Kew K, Newstead MW, Zeng X, Hogaboam CM, Krieg AM, Standiford TJ. Toll-like receptor 9 regulates the lung macrophage phenotype and host immunity in murine pneumonia caused by Legionella pneumophila. Infect Immun. 2008;76:2895-2904. doi: 10.1128/IAI.01489-07

8. Dane Parker, Alice Prince. Staphylococcus aureus induces type 1 interferon signaling in dendritic cells via TLR9. J Immunol. 2012 Oct 15; 189(8): 4040-4046. doi: 10.4049/jimmunol.1201055

9. Веклич К.А., Попов М.М., Лядова Т.І., Сорокіна О.Г. Аутоімунні маркери при коровій інфекції різного ступіня тяжкості. Актуальні проблеми сучасної медицини.
2020. Том 20, випуск 4 (72). с.11-16. doi 10.31718/2077-1096.20.4.11 . Veklych KA, Popov MM, Liadova TI, Sorokina OG autoimmune markers in measles infection of varying severity. Current problems of modern medicine. 2020. Volume 20, issue 4 (72). p. 11-16. doi 10.31718/2077-1096.20.4.11

10. Топтыгина А.П., Мамаева Т.А., Алешкин В.А., Особенности специфического гуморального иммунного ответа против вируса кори. Инфекция и иммунитет. 2013. Том 3, №3. с. 243-250. https://doi. org/10.15789/2220-7619-2013-3-243-250 .

11. Toptygina AP, Mamaeva TA, Aleshkin VA, Features of a specific humoral immune response against the measles virus. Infection and immunity. 2013. Volume 3, №3. p.243250. https://doi.org/10.15789/2220-76192013-3-243-250.

\section{PEЗ ЮME}

\section{ОСОБЛИВОСТI ЕКСПРЕСIÏ TOLL-LIKE РЕЦЕПTOPIB 9 ТИПУ НА ІМУНОКОМПЕТЕНТНИХ КЛІТИНАХ ПЕРИФЕРІЙНОЇ КРОВІ ПАЦІЕНТІВ 3 КОРОВОЮ ІНФЕКЦІЕЮ РІЗНОГО СТУПЕНЯ ТЯЖКОСТІ}

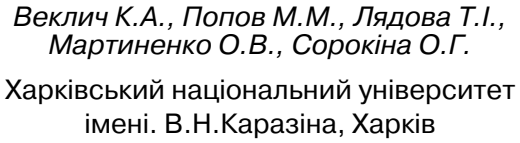

Мета дослідження: визначення рівню експресії Toll-like рецепторів 9 типу на лімфоцитах та моноцитах периферійної крові у пацієнтів з кором різного ступеня тяжкості як з ускладненнями, так і без них.

Матеріали та методи. У дослідження було включено 65 пацієнтів з діагнозом «кір», що знаходились на лікуванні у КЗОЗ КНП ХОР ОКІЛ в період з 2017 до 2019 роки. В залежності від тяжкості перебігу захворювання та наявності ускладнень пацієнти, залучені у дослідження, були розділені на 4 групи. Контрольну групу склали 20 добровільних донорів, що на момент відбору зразків крові не мали критеріїв виключення.

Усім пацієнтам у день надходження до стаціонару проводилось визначення у суспензії лейкоцитів рівню експресії Toll-like рецепторів 9 типу, концентрації у сироватці крові про- та протизапальних цитокінів (ІЛ-1, ІЛ-6, ІЛ-4, ІЛ-10) та інтерферонів альфа і гамма, а також визначення рівня у сироватці крові вірусспецифічних імуноглобулінів класів $\mathrm{M}, \mathrm{A}$ та $\mathrm{G}$ з рівнем авідності останніх. На підставі отриманих даних було проведено кореляційний аналіз між показниками рівню експресії Toll-like рецепторів та рівнями продукції вказаних показників.

Результати. Проведена робота дозволила виявити серед пацієнтів з кором три типи цитокінового реагування - нормореактивний, дисоціативний та гіпореактивний, кожен з яких характеризується різним характером реакції цитокінової мережі на корову інфекцію та має прямий зв'зок з тяжкістю перебігу захворювання та ризиком розвитку ускладнень. 
Встановлено, що корова інфекція у дорослого населення розвивається на фоні низьких титрів специфічних антитіл і їх низької авідності, а тяжкий перебіг захворювання в певній мірі обумовлюється реакцією імунної системи за первинним типом, що підтверджується високими рівнями специфічних IgМ на початку захворювання.

Аналіз даних, отриманих при вивченні рівню експресії Toll-like рецепторів 9 типу, продемонстрував, що в пацієнтів 1 та 2 груп, що мали нормореактивний тип цитокінового реагування та достовірно вищі рівні IgA та IgG, рівень експресії TLR9 на мононуклеарах периферійної крові був вищим, ніж у осіб контрольної групи. У пацієнтів 3 групи, що мали дисоціативний тип цитокінового реагування та більш значне, у порівнянні з пацієнтами 1 та 2 груп, зниження рівнів $\lg A$ та $\lg G$, рівень експресії TLR9 був у 1,33 рази нижчий, ніж у осіб контрольної групи. У пацієнтів 4 групи, що мали гіпореактивний тип цитокінового реагування та статистично значуще зниження рівнів IgA та IgG, рівень експресії TLR9 був найнижчим; у пацієнтів цієї групи показник експресії TLR9 був у 1,35 рази нижчий, ніж у осіб контрольної групи

Проведення кореляційного аналізу Пірсона, проведеного щодо показників в день надходження пацієнтів до стаціонару, продемонструвало наявність прямого кореляційного зв'язку між рівнем експресії TLR9 та рівнем у сироватці крові інтерферону альфа, інтерферону гамма та прозапальних цитокінів (ІЛ-1 та ІЛ-6). У відношенні протизапальних цитокінів - інтерлейкінів 4 та 10 - встановлено зворотній кореляційний зв'язок.

Висновки. Тяжкість перебігу корової інфекції асоціюється з рівнем експресії Toll-like рецепторів 9 типу.

Рівень експресії TLR9 знаходиться у прямому кореляційному зв'язку з активністю продукції прозапальних цитокінів, інтерферонів альфа та гамма і може розглядатися як фактор, що впливає на стан імунної відповіді на корову інфекцію.

Зниження активності експресії TLR9 на мононуклеарах може розглядатися як фактор тяжкості перебігу корової інфекції і її ускладнень, ризику розвитку бактеріальної пневмонії.

Дослідження порушення активності експресії TLR9 на імунокомпетентних клітинах переферійної крові може використовуватися для більш глибокого розуміння порушень імунної системи у пацієнтів із вірусними захворюваннями у якості предиктора та можливого фактора тяжкого перебігу захворювання та розвитку ускладнень.

Ключові слова: кір, Toll-like рецептори, інтерферон, цитокіни, імуноглобуліни.

\section{PЕЗЮME \\ ОСОБЕННОСТИ ЭКСПРЕССИИ TOLL-LIKE РEЦЕПTOРОВ 9 TИПA HA ИММУНОКОМПЕТЕНТНЫХ КЛЕТКАХ ПЕРИФИРИЧЕСКОЙ КРОВИ ПАЦИЕНТОВ С КОРЕВОЙ ИНФЕКЦИЕЙ РАЗЛИЧНОЙ СТЕПЕНИ ТЯЖЕСТИ}

Веклич К.А., Попов Н.Н., Лядова Т.И., Мартыненко А.В., Сорокина О.Г.

Харьковский национальный университет имени В.Н.Каразина

Цель исследования: определение уровня экспрессии Toll-like рецептора 9 типа на мононуклеарах периферической крови у пациентов с коревой инфекцией различной степени тяжести, как с осложнениями, так и без них.

Материалы и методы. В исследование было включено 65 пациентов с диагнозом «корь», находившихся на стационарном лечении в КПЗО КНП ХОС ОКИБ в период с 2017 по 2019 гг. В зависимости от степени тяжести заболевания и наличия осложнений, пациенты были разделены на 4 группы. Контрольную группу составляли 20 добровольных доноров, которые на момент отбора образцов крови не имели критериев исключения.

Всем пациентам в день поступления в стационар проводилось определение в суспензии лейкоцитов уровня экспрессии Toll-like рецепторов 9 типа, концентрация в сыворотке крови про- и противовоспалительных цитокинов (ИЛ-1, ИЛ-6, иЛ-4, иЛ-10) и интерферонов альфа и гамма, а также определение в сыворотке крови уровня вирус-специфических иммуноглобулинов классов М, А и G с определением уровня авидности последних. На основании полученных данных проводился корреляционный анализ между показателями уровня экспресии Toll-like рецепторов 9 и уровнями продукции указанных показателей.

Результаты. Проведенная работа позволила выявить среди пациентов с корью три типа цитокинового реагирования - нормореактивный, диссоциативный и гипореактивный, каждый из которых характеризуется различным характером реагирования цитокиновой сети на коревую инфекцию и имеет прямую связь с тяжестью течения заболевания и риском развития осложнений.

Установлено, что коревая инфекция у взрослого населения развивается на фоне низких титров специфичных антител и низкой их авидности, а тяжелое течение заболевания в некоторой степени обуславливается реакцией иммунной системы по первичному типу, что подтверждается высокими уровнями специфических IgM в начале заболевания.

Анализ данных, полученных при изучении уровня Toll-like рецепторов 9 типа, показал, что у пациентов 1 и 2 групп, которые имели нормореактивный тип цитокинового реагирования и достоверно более высокие уровни IgA и IgG, уровень экспрессии TLR9 на мононуклеарах периферической крови был выше, чем у лиц контрольной группы. У пациентов 3 группы, которые имели диссоциативный тип иммунного реагирования и более значительное, по сравнению 
с пациентами 1 и 2 групп, снижение уровней IgA и $\operatorname{lgG}$, уровень экспрессии TLR9 был в 1,33 раза ниже, чем у лиц контрольной группы. У пациентов 4 группы, которые имели гипореактивный характер цитокинового реагирования и статистически значимое снижение уровней IgA и IgG, уровень экспрессии TLR9 был самым низким; у пациентов этой группы показатель экспрессии TLR9 был в 1,35 раз ниже, чем у лиц контрольной группы.

Корреляционный анализ Пирсона, проведенный в отношении показателей в день поступления пациентов в стационар, продемонстрировал наличие прямой корреляционной связи между уровнем экспрессии TLR9 и уровнем в сыворотке крови интерферона альфа и гамма, и провоспалительных цитокинов (ИЛ-1, ИЛ-6). В отношении противовоспалительных цитокинов - ИЛ-4 и ИЛ-10 - установлена обратная корреляционная связь.

Выводы. Тяжесть течения коревой инфекции ассоциируется с уровнем экспресии Toll-like рецепторов 9 типа.

Уровень экспресии TLR9 находится в прямой корреляционной связи с активностью продукции провоспалительных цитокинов, интерферонов альфа и гамма и может рассматриваться как фактор, влияющий на состояние иммунного ответа на коревую инфекцию.

Снижение активности экспрессии TLR9 на мононуклеарах может рассматриваться как фактор тяжести течения коревой инфекции и ее осложнений, риска развития бактериальной пневмонии.

Исследования нарушений активности экспресии TLR9 на иммунокомпетентных клетках периферической крови может использоваться для более глубокого понимания нарушений иммунной системы у пациентов с вирусными заболеваниями в качестве предиктора и возможного фактора тяжелого течения заболевания и развития осложнений.

Ключевые слова: корь, Toll-like рецепторы, интерферон, цитокины, иммуноглобулины.

\section{SUMMARY}

\section{FEATURES OF THE EXPRESSION OF TOLL-LIKE RECEPTORS TYPE 9 ON IMMUNOCOMPETENT PERIPHERAL BLOOD CELLS OF PATIENTS WITH MEASLES INFECTION OF VARYING SEVERITY}

Veklych K., Popov M., Liadova T., Martynenko A., Sorokina O. V. N. Karazin Kharkiv National University

Aim of the study: to determine the level of Toll-like receptor type 9 expression on peripheral blood mononuclears in patients with measles infection of varying severity, both with and without complications.

Materials and methods. The study included 65 patients with a diagnosis of measles who were on inpatient treatment in the Kharkiv region infectious hospital in the period from 2017 to 2019 years. Depending on the severity of the disease and the presence of complications the patients were divided into 4 groups. The control group consisted of 20 voluntary donors who did not have the exclusion criteria at the time of blood sampling.
All patients on the day of admission to the hospital underwent assessment of the level of Tolllike receptors type 9 expression in the white blood cell suspension, the concentration in the blood serum of pro- and anti-inflammatory cytokines (IL-1, IL-6, IL-4, $\mathrm{IL}-10)$ and interferons alpha and gamma, as well as the determination in the blood serum of the level of virusspecific immunoglobulins of $\mathrm{M}, \mathrm{A}$ and $\mathrm{G}$ classes with the determination of the level of avidity of the latter. Based on the obtained data a correlation analysis between the indicators of the level of Toll-like receptors type 9 expression and the levels of production of mentioned indices was performed.

Results. The study revealed three types of cytokine response among patients with measles - normoreactive, dissociative, and hyporeactive, each of which is characterized by a different nature of the cytokine network response to measles infection and has a direct relationship with the severity of the disease and the risk of complications.

It was found that measles infection in the adult population develops against the background of low titers of specific antibodies and their low avidity, and the severe course of the disease is to some extent caused by the reaction of the immune system according to the primary type, which is confirmed by high levels of specific $\operatorname{lgM}$ at the beginning of the disease.

Analysis of the data obtained when studying the level of Toll-like receptors type 9 showed that in patients of groups 1 and 2, who had a normoreactive type of cytokine response and significantly higher levels of $\lg A$ and IgG, the level of TLR9 expression on peripheral blood mononuclears was higher than in the control group. In patients of group 3, who had a dissociative type of immune response and a more significant decrease in IgA and IgG levels compared to patients of groups 1 and 2, the level of TLR9 expression was 1.33 times lower than in the control group. In group 4 patients who had a hyporeactive cytokine response and a statistically significant decrease in IgA and IgG levels, the level of TLR9 expression was the lowest; in patients of this group, the TLR9 expression index was 1.35 times lower than in the control group.

Pearson's correlation analysis of the indices on the day of admission to the hospital showed a direct correlation between the level of TLR9 expression and the level of interferon alpha and gamma in the blood serum, as well as level of proinflammatory cytokines (IL-1, IL-6). An inverse correlation was established with respect to antiinflammatory cytokines-IL-4 and IL-10.

Conclusions. The severity of measles infection is associated with the level of Toll-like receptors type 9 expression.

The level of TLR9 expression is directly correlated with the activity of proinflammatory cytokines, interferons alpha and gamma production and can be considered as a factor affecting the state of the immune response to measles infection.

A decrease in the activity of TLR9 expression on mononuclears can be considered as a factor of the severity of the course of measles infection and its complications, and the risk of bacterial pneumonia. 
Studies of violations of TLR9 expression activity on immunocompetent peripheral blood cells can be used to better understand the immune system disorders in patients with viral diseases as a predictor and possible factor of severe disease and the development of complications.

Key words: measles, Toll-like receptors, interferon, cytokines, immunoglobulins.

\section{- Веклич Ксенія Артемівна асистент кафедри загальної та клінічної іму- нології та алергології, \\ Харківський національний університет імені В.Н.Каразіна. \\ м.Харків, Україна \\ тел.: (057) 707-54-50 \\ E-mail: kseniia_veklych@ukr.net}

\section{- Попов Микола Миколайович} доктор медичних наук, професор кафедри клінічної імунології та алергології, Харківський національний університет імені В.Н.Каразіна.

м.Харків, Україна

тел.: (057) 707-54-50

E-mail:m.popov@karazin.ua

\section{- Лядова Тетяна Іванівна} доктор медичних наук, професор, завідувачка кафедри клінічної імунології та алергології,

Харківський національний університет імені В.Н.Каразіна.

м.Харків, Україна

тел.: (057) 707-54-50

E-mail: t.liadova@karazin.ua

\section{- Мартиненко Олександр Віталійович}

доктор фізико-математичних наук, професор кафедри гігієни и соціальної медицини, Харківський національний університет імені В.Н.Каразіна.

м.Харків, Україна

тел.: (057) 702-04-55

E-mail: alexander.v.martynenko@karazin.ua

\section{- Сорокіна Ольга Георгіївна}

кандидат медичних наук, доцент кафедри загальної та клінічної імунології та әлергології,

Харківський національний університет імені В.Н.Каразіна.

м.Харків, Україна

тел.: (066) 2634884

E-mail: olga-sorokina@ukr.net

\section{АВТОРСЬКА ДОВІДКА}

- Веклич Ксения Артемовна ассистент кафедры общей и клинической иммунологии и алергологии,

Харковський национальный университет имени В.Н.Каразина.

г.Харьков, Украина

тел.: (057) 707-54-50

E-mail: kseniia_veklych@ukr.net

\section{- Попов Николай Николаевич} доктор медицинских наук, профессор кафедры общей и клинической иммунологии и алергологии,

Харковський национальный университет имени В.Н.Каразина.

г.Харьков, Украина

тел.: (057) 707-54-50

E-mail: m.popov@karazin.ua

\section{- Лядова Татьяна Ивановна}

доктор медицинских наук, профессор, заведующая кафедрой общей и клинической иммунологии и алергологии,

Харковський национальный университет имени В.Н.Каразина.

г.Харьков, Украина

тел.: (057) 707-54-50

E-mail: t.liadova@karazin.ua

\section{- Мартыненко Александр Витальевич}

доктор физико-математических наук, профессор кафедры гигиены и социальной медицины, Харковський национальный университет имени В.Н.Каразина.

г.Харьков, Украина

тел.: (057) 702-04-55

E-mail: alexander.v.martynenko@karazin.ua

\section{- Сорокина Ольга Георгиевна}

кандидат медицинских наук, доцент кафедры общей и клинической иммунологии и алергологии,

Харковський национальный университет имени В.Н.Каразина.

г.Харьков, Украина

тел.: (066) 2634884

E-mail: olga-sorokina@ukr.net

\section{- Veklich Kseniia}

Assistant of Department of General and Clinical Immunology and Allergology, V.N. Karazin Kharkiv National University Kharkiv, Ukraine tel.: (057) 707-54-50

E-mail: kseniia veklych@ukr.net

\section{- Popov Mykola}

Doctor of Medicine, Professor of Department of General and Clinical Immunology and Allergology,

V.N. Karazin Kharkiv National University Kharkiv, Ukraine

tel.: (057) 707-54-50

E-mail: m.popov@karazin.ua

\section{- Liadova Tetiana}

Doctor of Medicine, Professor, Head of the Department of General and Clinical Immunology and Allergology,

V.N. Karazin Kharkiv National University, Kharkiv, Ukraine tel.: (057) 707-54-50

E-mail: t.liadova@karazin.ua

\section{- Martynenko Oleksander}

Doctor of Physical and Mathematical Sciences, Professor of Department of Hygiene and Social Medicine

V.N. Karazin Kharkiv National University, Kharkiv, Ukraine tel.: (057) 702-04-55

E-mail: alexander.v.martynenko@karazin.ua

\section{- Sorokina Olga}

Candidate of Medical Sciences, Associate Professor of Department of General and Clinical Immunology and Allergology, V.N. Karazin Kharkiv National University. Kharkiv, Ukraine tel.: (066) 2634884 E-mail: olga-sorokina@ukr.net 